\title{
USES AND GRATIFICATIONS OF GENTA MAGAZINES AMONG PETRA CHRISTIAN UNIVERSITY'S STUDENT
}

\section{Motif dan Kepuasan Mahasiswa Universitas Kristen Petra sebagai Pembaca Majalah Genta}

\author{
Felicia Luvena $^{1)}$, Veronica Maureen ${ }^{2)}$, Fanny Lesmana ${ }^{3)}$ \\ 1) Ilmu Komunikasi, Universitas Kristen PetraSurabaya \\ 2) Ilmu Komunikasi, Universitas Kristen Petra Surabaya \\ 3) Ilmu Komunikasi, Universitas Kristen Petra Surabaya
}

Diterima 20 Januari 2019/ Disetujui 29 Maret 2019

\begin{abstract}
GENTA Magazine was published by student press known as Pers Mahasiswa (PERSMA) of Petra Christian University since January 28th, 1964 and also the oldest campus magazine in Indonesia. GENTA Magazine intended for Petra Christian University community. But, because it is made by the student press, in this paper we tried to focus on the student audience. In principle, GENTA Magazine is an internal media.

The study aimed to know about GENTA Magazine's reader's gratifications, especially the students of Petra Christian University. The students were asked to rate their reason to read GENTA Magazine based on those statements that operationalized in 5-point Likert scale (5=exactly, $1=$ not at all). The instrument was divided into two parts: the first part, they were asked to answer basic identity (gender and major). And in the final section they were asked about motivations in reading GENTA Magazine that divided again into 3 categories based on Stafford, Stafford \& Schkade (2004) meta-categorization of gratification factors (Social Gratifications, Content Gratifications, and Process Gratifications). This research will be value-able to the magazines publishers to adapt with their audience motives and needs from the magazines. The student press, as the publishers might have more understanding of how to make their contents of the magazine and have better understanding how of how to get the audience attention's. The findings revealed that Petra Christian University's students' gratifications are fulfilled in content gratification indicator
\end{abstract}

Keywords; magazine, media consumptions, uses and gratifications

\begin{abstract}
ABSTRAK
Majalah GENTA diterbitkan oleh pers mahasiswa yang dikenal sebagai Pers Mahasiswa (PERSMA) Universitas Kristen Petra sejak 28 Januari 1964 dan juga majalah kampus tertua di Indonesia. Majalah GENTA ditujukan untuk komunitas Universitas Kristen Petra. Tetapi, karena dibuat oleh pers siswa, dalam makalah ini kami mencoba untuk fokus pada audiensi siswa. Pada prinsipnya, Majalah GENTA adalah media internal.

Penelitian ini bertujuan untuk mengetahui tentang kepuasan pembaca Majalah GENTA, terutama mahasiswa Universitas Kristen Petra. Para siswa diminta untuk menilai alasan mereka untuk membaca Majalah GENTA berdasarkan pernyataan-pernyataan yang dioperasionalkan dalam skala Likert 5 poin $(5=$ tepatnya, $1=$ tidak sama sekali). Instrumen ini dibagi menjadi dua bagian: bagian pertama, mereka diminta untuk menjawab identitas dasar (gender dan utama). Dan pada bagian terakhir mereka ditanya tentang motivasi dalam membaca Majalah GENTA yang dibagi lagi menjadi 3 kategori berdasarkan meta-kategorisasi faktor-faktor kepuasan(Gratifikasi Sosial, Gratifikasi Konten, dan Gratifikasi Proses). Penelitian ini akan bermanfaat bagi penerbit majalah untuk beradaptasi dengan motif dan kebutuhan audiens mereka dari majalah tersebut. Pers mahasiswa, karena penerbit mungkin memiliki lebih banyak pemahaman tentang bagaimana membuat konten majalah mereka dan memiliki pemahaman yang lebih baik tentang bagaimana cara mendapatkan perhatian penonton. Temuan mengungkapkan bahwa gratifikasi mahasiswa Universitas Kristen Petra terpenuhi dalam indikator kepuasan konten

Kata kunci; majalah, konsumsi media, penggunaan dan kepuasan.
\end{abstract}




\section{INTRODUCTION}

Uses and gratifications theory - a research approach that used to understanding audience consumption of traditional media (Ruggiero, 2000) would be an appropriate theory to knowing about audience's motives of their usage of media. In terms that the audience an active audience that define that they make the conscious decisions about what media they consume (McQuail, 2007).

According to Miller (2004), Uses and gratifications theory began to conceive the audience motives as gratifications that were obtained by individuals from the media. Because this research featured the ability of the audience to provide information from the media, so they are an active audience which knowing their motives and desires to the media.

Uses and gratifications theory takes a different approach to understand media than do most of the theorie scholars apply to analyses of magazine content and the impact that content has on the publication's readership (Filak, 2015, p.261). U\&G theory attempt to understand what audiences do with the media, while the most theoritical approaches seek to understand what media do.

According to Filak (2015), with U\&G perspective, scholars have posited that some biological and psychological need are innate to the human condition. The readers will seek out sources to satisfy their needs and they will repeatedly return to the magazine.

The 5 key assumptions to $U \& G$ and media use; (1) active audience, (2) the goal is to use media, (3) media consumption satisfies a wide range of needs, (4) people knowing why they use the media, and (5) gratifications can be obtained through the use of media.

Individuals as a reader tend to seek specific kinds of media to satisfy their needs. They are actively pursuing the media to find out their goals and will continue to return to those media that best satisfied their needs. The media can provide a wide array of gratifications, even within specific format and through that the readers get multiple needs.

*Author Correspondence:

E-mail: flesmana@petra.ac.id
There are also some flaws in U\&G theory, the first one is because in this theory just focusing on audience consumption so that often make this too individualistic and make it more difficult to predict beyond the audience thought. Second, there are many studies that differentiate the type of the motives that caused it hinder to conceptualize it, because it not integrated one to each other.

According to Rosengren (1974), personal characteristics and social environment of the individual could produce perceive problems and perceived solutions. That problems and solutions could set up different motives for gratification behavior from using media.

The area of internal communication has expanded and recognized as an effective public relations strategy. Each organization will have at least an internal media as a bridge of communication between management and their public. Internal media is a tool of communication that used to deliver any information from the organization to their public (Gani, 2013). Therefore, this media will support the flow of communication that depict the image of the organization to their public.

GENTA Magazine was published by student press known as Pers Mahasiswa (PERSMA) of Petra Christian University since January 28th, 1964 and also the oldest campus magazine in Indonesia. GENTA Magazine intended for Petra Christian University community. But, because it is made by the student press, in this paper we tried to focus on

the student audience. In principle, GENTA Magazine is an internal media.

Simple definition of student press is a press that runs by the students. The differences with the usual press are their editorial and management reflect the student's character. It is one way for them to distribute their creativity, thoughts through writings and actualize themselves in the organizations. Ideally, the students press will socialize the thought and problems that happening in the middle of the campus or even in the society (Mohamad, Pan Faiz, 2006).

According to Achmad (2014) press means each media communication such as, book, magazine, newspaper, radio or television. Like the other normal news media, student press media often have the same legal guidelines compared to the other practical 
standards (Roinicki, 2008) There are 4 essential function of press according to Indonesian Press Policies number 40 (1999); education function, information, entertainment and social control.

Schramm et. al (1986) mention that information function as the number one press function, press should contain information about event, idea or thoughts, etc. Education function means that press as a medium to produce writings that contain knowledge (Schramm et. al. 1986). So that, GENTA Magazine should provide so that the audience could get new knowledge. And to balance those two functions, press also have the entertainment function. And last, press also have the social control function that indicate the content able to persuade the readers to do or believe in something. Even, according to Achmad (2014) press have the control to the policies that have been made.

College students considered have dynamic nuances and scientific attitudes in seeing things based on objective, systematic and rational reality. In fact, Achmad (2014) also mention that the student movement in 1998 influence by the existence of student press. Student press also believed as the powerful medium to deliver aspirations. So, ideally GENTA Magazine should provide the aspirations from all parties in Petra Christian University.

According to tirto.id the level of reading interest in Indonesia is lower compared to the others countries. From 61 countries, Indonesia ranked 60th as Najwa Shihab said in the "Literation Meeting" held by the Lembaga Garda Lamaholot and the ministry of art and education. This fact is also caused by the lower number of the reading ability in Indonesia. With this fact, GENTA as one of the oldest student press in Indonesia should know about the audience.

The readership of GENTA Magazines targeted at the students as the audience will be investigated in this research. As the print media industry facing their challenge in this modern and global era, to understanding the consumption tendencies and motives will help and answer the problems and help the industry to stay keep up with the internet things.

This research will be value-able to the magazines publishers to adapt with their audience motives and needs from the magazines. The student press, as the publishers might have more understanding of how to make their contents of the magazine and have better understanding how of how to get the audience attention's.

This purpose of this study is to examine the motives of Petra Christian University's students for reading GENTA Magazines. U\&G is used to identify the audience's motives of their usage of media, in this case GENTA Magazines as the internal media of Petra Christian University. Based on this background, this study will seek to research question as follow:

\section{What is the gratifications motives of Petra Christian University's students for reading GENTA Magazines?}

This study is used the sample from total population of 2016 and 2017 batch of Petra Christian University. The gratification motives and media use of Petra Christian University's students for reading GENTA Magazines. This means that the findings can be generalized to the population of Petra Christian University's student.

\section{RESEARCH METHODOLOGY}

Based on the previous research by

M.G. Jere \& S.V. Davis, we find thirty gratification statements to measure the motivation for reading magazine drawn from some previous UGT studies. In previous research the 30 gratifications grouped into 10 categories to capture the gratifications and we modified to 9 categories to adjust with our respondents. The statements list provided in the table below.

The respondents were asked to rate their reason to read GENTA Magazine based on those statements that operationalized in 5 - point Likert scale (5=exactly, $1=$ not at all). The instrument was divided into two parts: the first part, they were asked to answer basic identity (gender and major). And in the final section they were asked about motivations in reading GENTA Magazine that divided again into 3 categories based on Stafford, Stafford \& Schkade (2004) meta-categorization of gratification factors (Social Gratifications, Content Gratifications, and Process Gratifications). 


\section{RESULTS AND ANALYSIS}

\section{Descriptive Statistic of the Sample}

There are 6 faculties in Petra Christian University with total of 26 departments (based on the latest data from July 2018). This research only received response from students of batch 2016 and batch 2017 because those students already read 10 new editions of GENTA Magazine.

The online survey drew 136 respondents. As the study focused on 2016 and 2017 students, responses from 2015 and 2018 students and incomplete questionnaire were excluded from analysis, leaving 100 responses for analysis of which $52 \%$ were female and $48 \%$ were male.

Table 1. Total Students of Petra Christian University Batch 2016 and 2017

\begin{tabular}{ll}
\hline \multicolumn{1}{c}{ Faculty } & Students \\
\hline $\begin{array}{l}\text { Faculty of Letters } \\
\text { English Literature(English\& Chinese) }\end{array}$ & 131 students \\
\hline English for Creative Industry & 49 students \\
\hline $\begin{array}{l}\text { Faculty of Civil and Planning } \\
\text { Engineering(Architecture\& Civil) }\end{array}$ & 652 students \\
\hline $\begin{array}{l}\text { Faculty of Industrial Technology } \\
\text { Engineering(Electrical, Mechanical, Automotive, }\end{array}$ & \\
$\begin{array}{l}\text { Informatics, Industrial, International Business) } \\
\text { Business Information System }\end{array}$ & 716 students \\
\hline $\begin{array}{l}\text { Faculty of Economics } \\
\text { Management(Business, Hotel, Tourism and Leisure, }\end{array}$ & \\
$\begin{array}{l}\text { Financial, Marketing, International Business) } \\
\text { Accounting(Business, Tax, International Business) }\end{array}$ & 990 students \\
\hline $\begin{array}{l}\text { Faculty of Art and Design } \\
\text { Design(Interior, Visual Communication) } \\
\text { International Program in Digital Media }\end{array}$ & 350 students \\
\hline $\begin{array}{l}\text { Faculty of Communication Science } \\
\text { Communication Science }\end{array}$ & 22 students \\
\hline $\begin{array}{l}\text { Faculty of Teacher Education } \\
\text { Elementary School Teacher Education }\end{array}$ & 174 students \\
\hline
\end{tabular}

Source: Petra Christian University (July 2018)

The online survey drew 136 respondents. As the study focused on 2016 and 2017 students, responses from 2015 and 2018 students and incomplete questionnaire were excluded from analysis, leaving 100 responses for analysis of which $52 \%$ were female and $48 \%$

male 
Table 2. Sex Profile of Sample

\begin{tabular}{|c|c|c|c|c|}
\hline Male & 48 & & $48 \%$ & \\
\hline Female & 52 & & $52 \%$ & \\
\hline Total & 100 & & $100 \%$ & \\
\hline \multicolumn{5}{|l|}{ Source: Researcher } \\
\hline $\begin{array}{rr}\text { Table } & \text { 3. Population and } \\
\text { Sample }\end{array}$ & & & & \\
\hline Faculty & & Population & Sample & Percentage \\
\hline Faculty of Letters & & 180 students & 5 students & $5 \%$ \\
\hline Faculty of Civil and Planning & & 652 students & 18 students & $18 \%$ \\
\hline Faculty of Industrial Technology & & 766 students & 19 students & $19 \%$ \\
\hline Faculty of Economics & & 1360 students & 37 students & $37 \%$ \\
\hline Faculty of Art and Design & & 601 students & 15 students & $15 \%$ \\
\hline Faculty of Communication Science & & 174 students & 5 students & $5 \%$ \\
\hline Faculty of Teacher Education & & 37 students & 1 student & $1 \%$ \\
\hline Total & & $\begin{array}{l}\mathbf{3 7 5 0} \\
\text { students }\end{array}$ & $\begin{array}{c}100 \\
\text { students }\end{array}$ & $100 \%$ \\
\hline
\end{tabular}

Source: Researcher

\section{Categorization}

1. Social Gratification, Status $(1,2)$

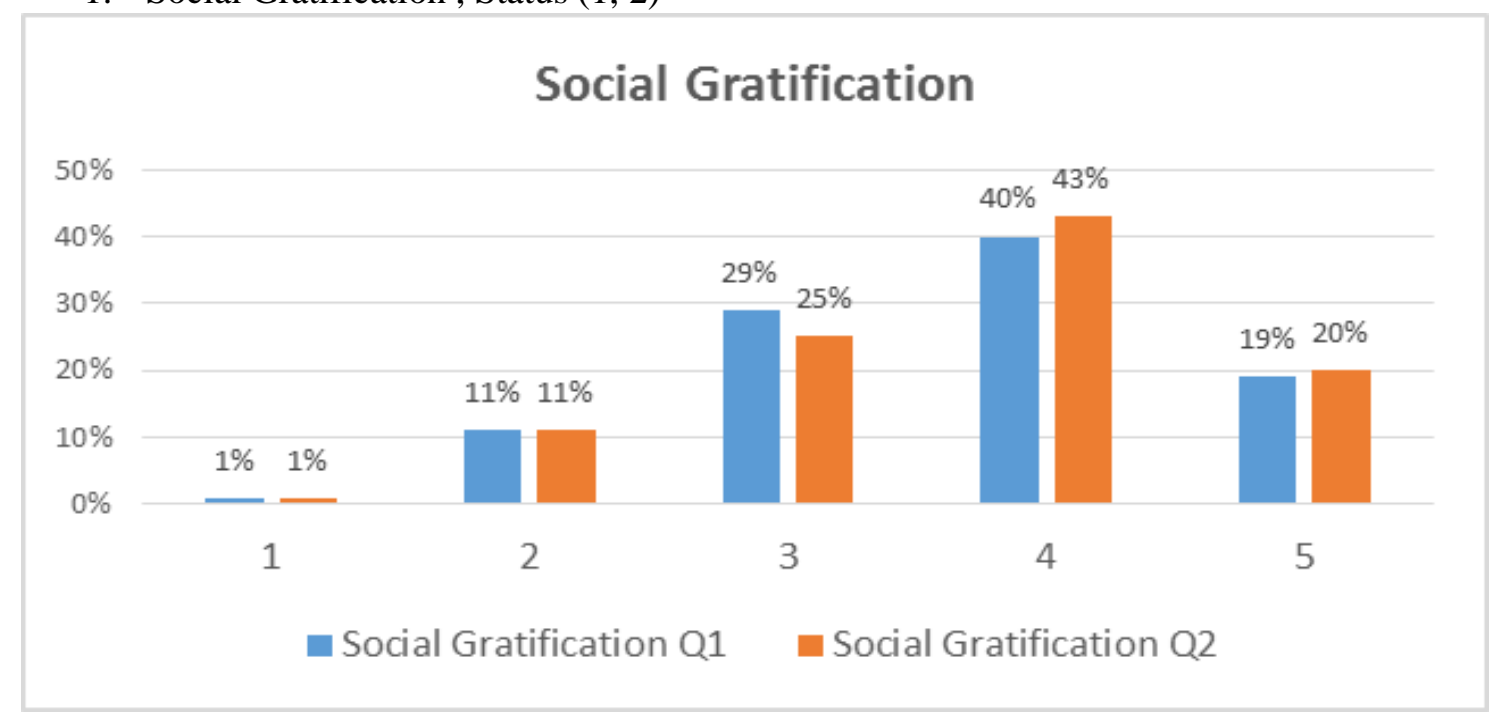

Picture 1. Social Gratifications-Status (Question 1, 2)

Source: Researcher 
Q1 : I read GENTA Magazine because "Tentang Petra" rubric make me up to date with everything happens in Petra Christian University

Q2 : I read GENTA Magazine because "Surabaya Corner" rubric make me up to date with everything happens in Surabaya.

2. Interpersonal Utility $(3,4)$

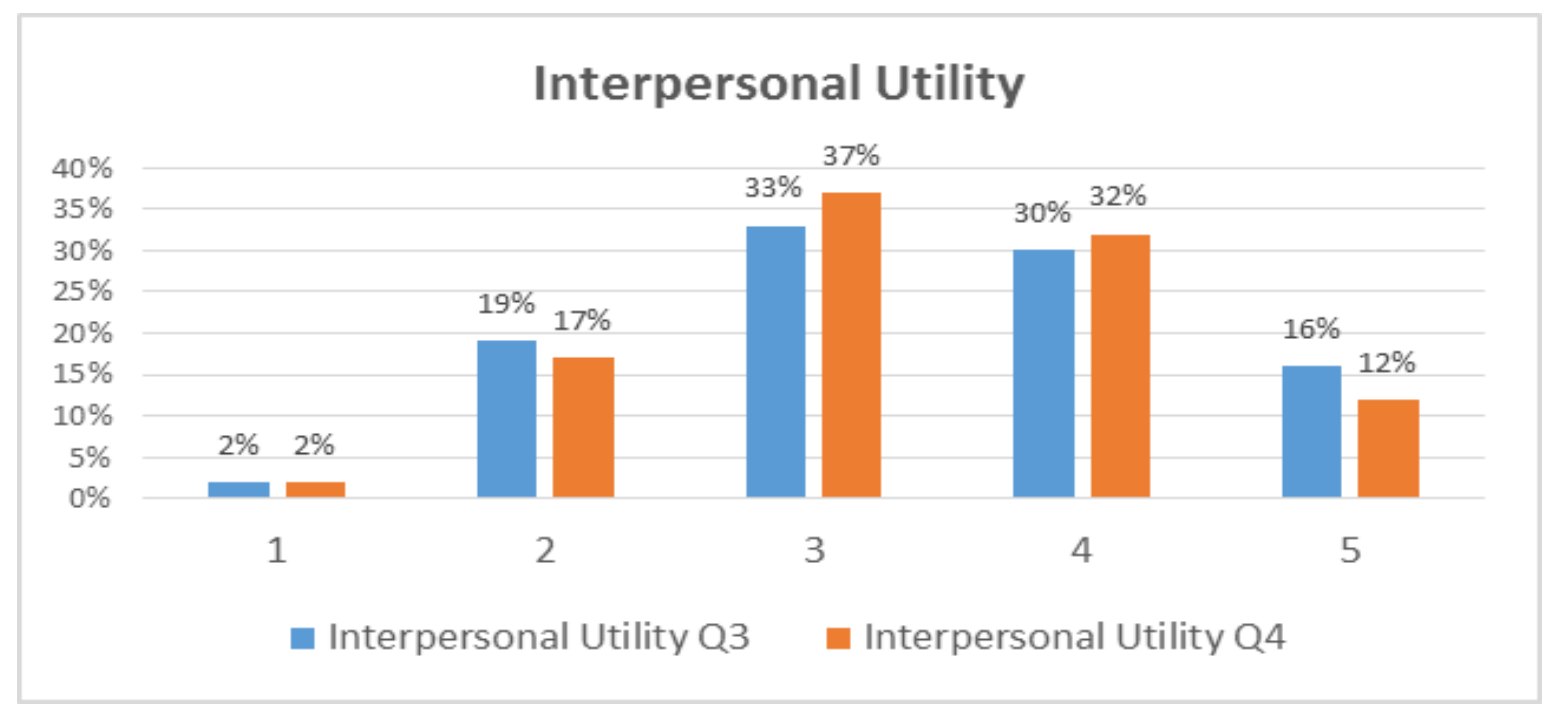

Picture 2. Social Gratifications Interpersonal Utility (Question 3,4)

Source: Researcher

Q3: I read GENTA Magazine because it makes me connected with people who share same interest $\mathrm{s}$ with me.

Q4: I read GENTA Magazine because it givesme space to express my minds.

3. Content Gratifications - Information Seeking $(5,6,7)$

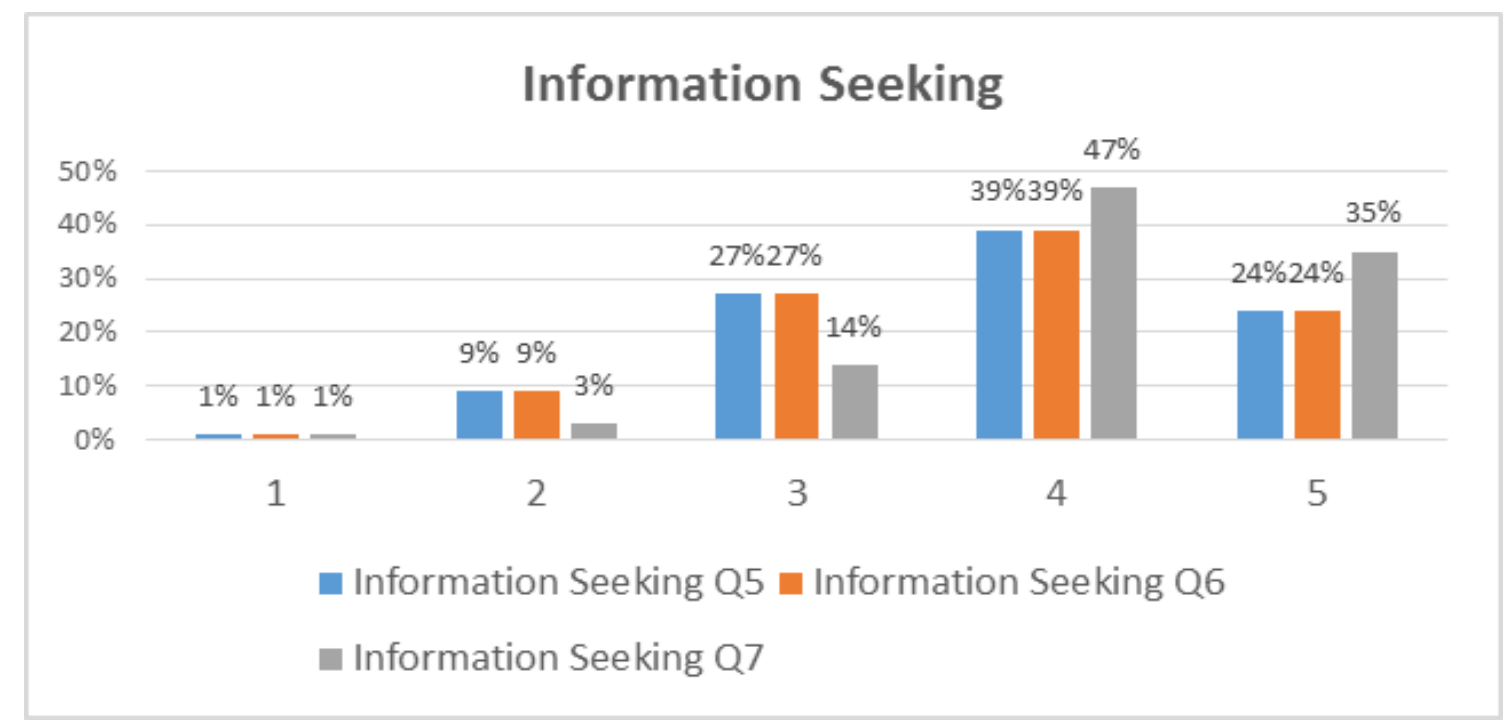

Picture 3. Content Gratifications-Information Seeking (Question 5,6,7)

Source: Researcher 
Q5: I read GENTA Magazine because it provide information quickly and cheaply

Q6 : I read GENTA Magazine because to know about actual and trusted issues

Q7 : I read GENTA Magazine because GENTA Magazine is trusted and reliable

4. Social Gratification - Surveillance $(8,9,10,11)$

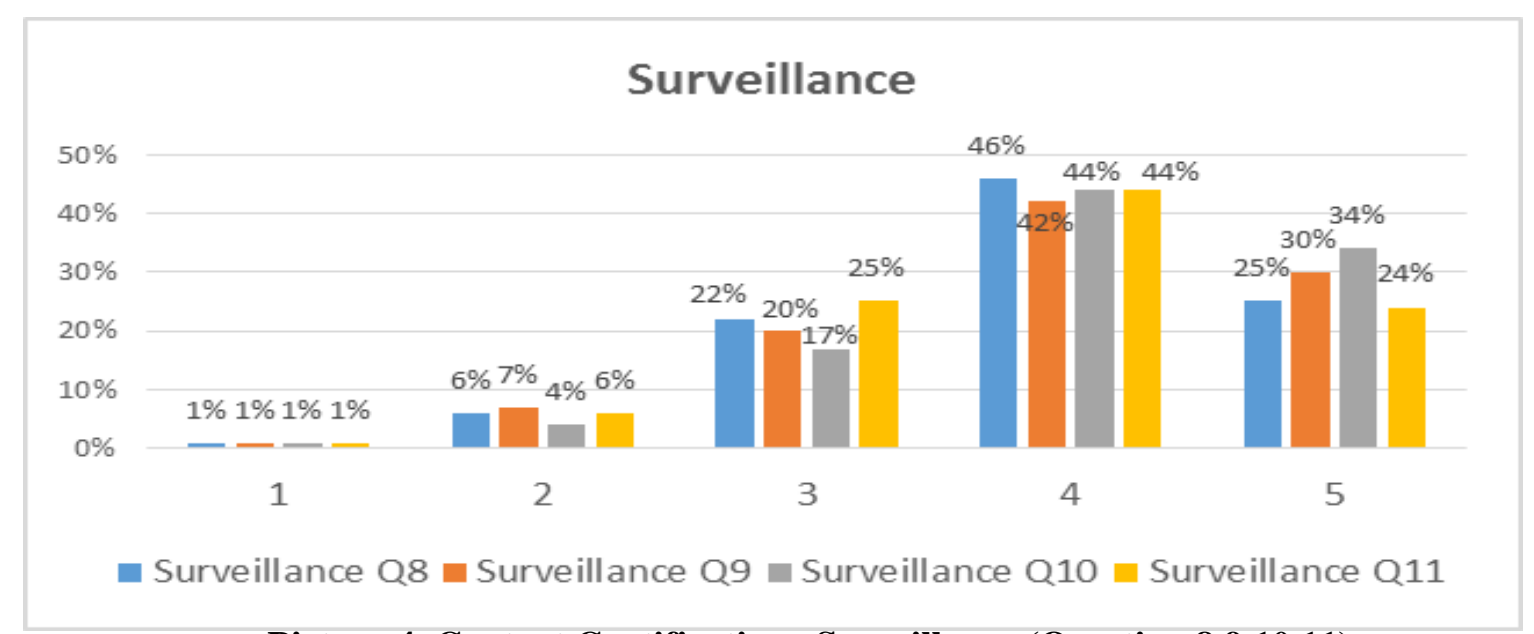

Picture 4. Content Gratifications-Surveillance (Question 8,9,10,11)

Source: Researcher

Q8: I read GENTA Magazine because "Surabaya Corner" rubric is gives new information about tourism destination in Surabaya

Q9 : I read GENTA Magazine because "Tentang Petra" rubric is gives information about new facilities and events in Petra Christian University

Q10 : : I read GENTA Magazine because "Tahukah Kamu" rubric is gives information about unique things in the world

Q11: I read GENTA Magazine because it always came up with interesting topics in every edition.

5. Self-Development $(12,13,14,15)$

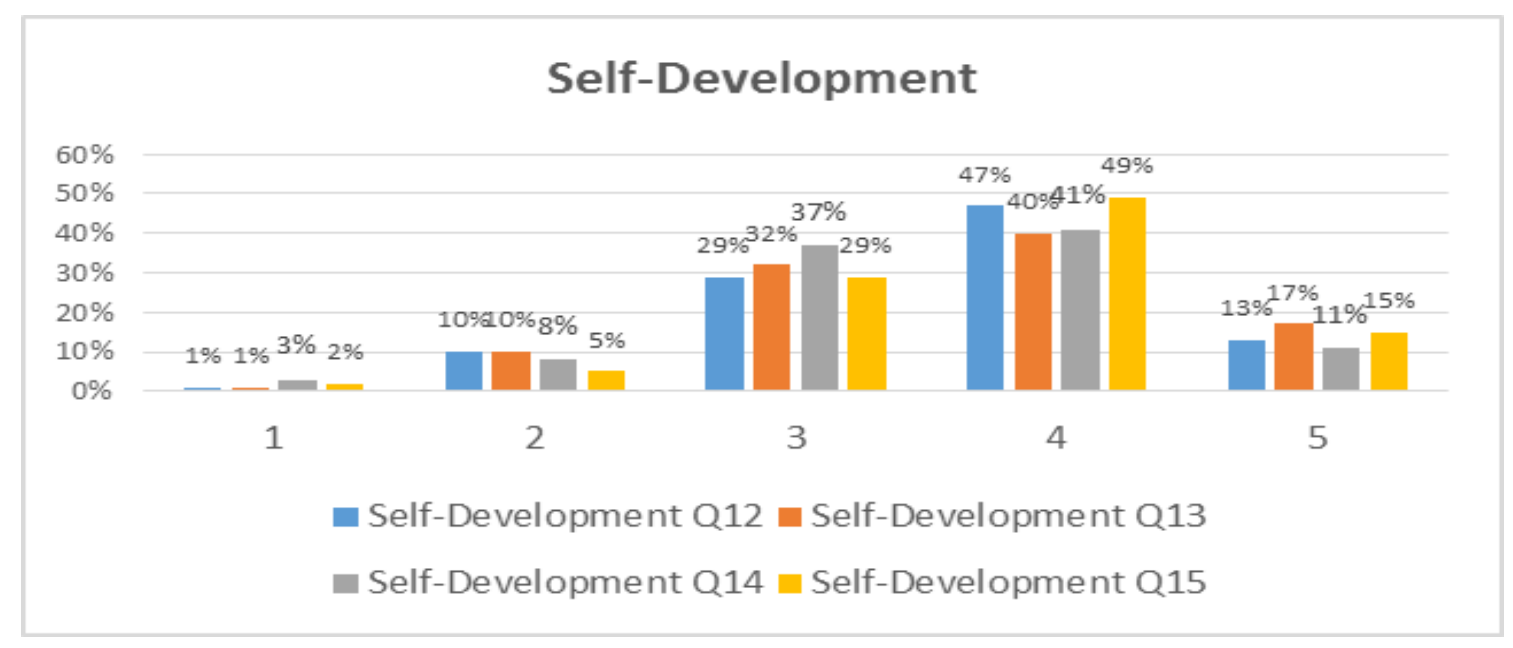

Picture 5. Content Gratifications-Self Development (Question 12,13)

Source: Researcher 
Q12: I read GENTA Magazine because it inspire me to create something

Q13: I read GENTA Magazine because it provides interesting ideas to develop myself.

Q14 : I read GENTA Magazine because "Renungan" rubric helps me to solve my problem Q15 : I read GENTA Magazine because "Jeda Inspirasi" rubric inspires me to be more active in student organization

6. Career Opportunities $(16,17)$

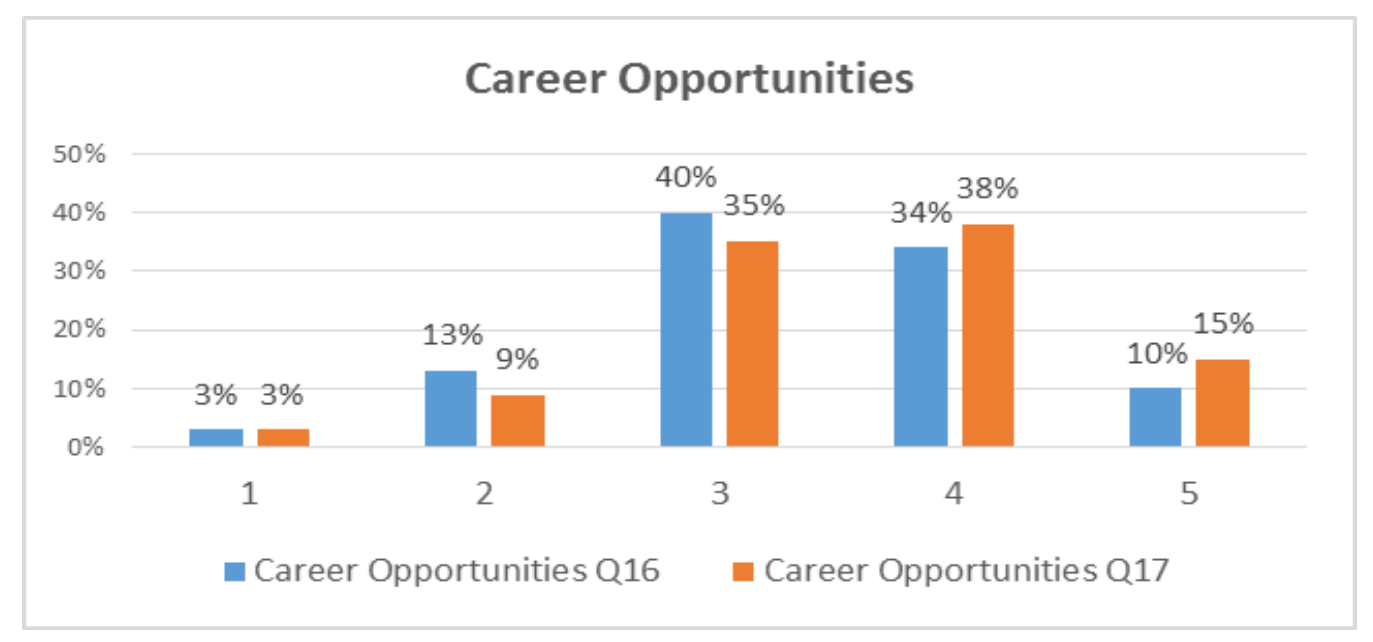

Picture 6. Content Gratifications-Self Development (Question 16,17)

Source: Researcher

Q16 : : I read GENTA Magazine because it helps me to decide the job that match to me Q17 : : I read GENTA Magazine because it provides information about what I should prepare for career matters

7. Diversion $(18,19,20,21)$

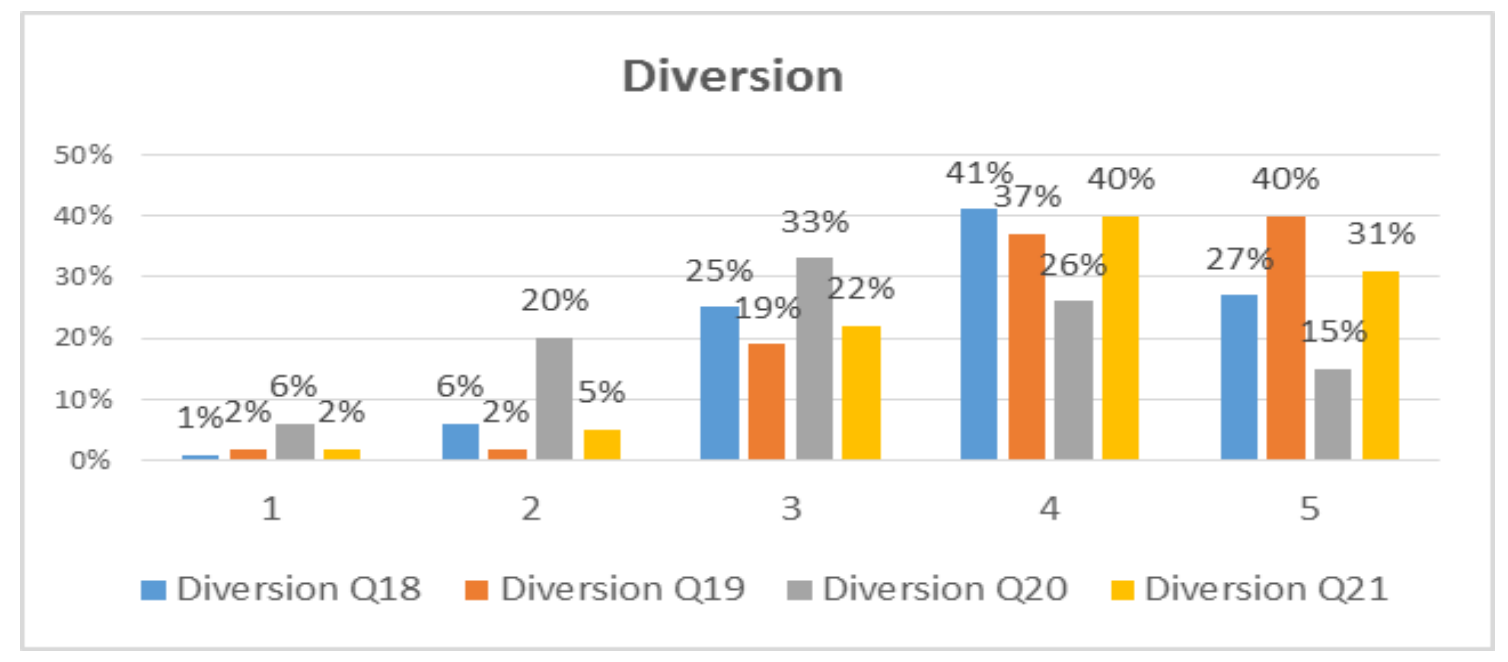

Picture 7. Content Gratifications-Diversion (Question 18,19)

Source: Researcher 
Q18 : I read GENTA Magazine because "Rekaman Lensa" rubric is entertains me.

Q19 : I read GENTA Magazine because it has good quality of photo and illustrations.

Q20 : I read GENTA Magazine because it makes me forget about time and distract me from my daily activity.

Q21 : I read GENTA Magazine because to pass time and to look for entertainment.

8. Economy $(22,23)$

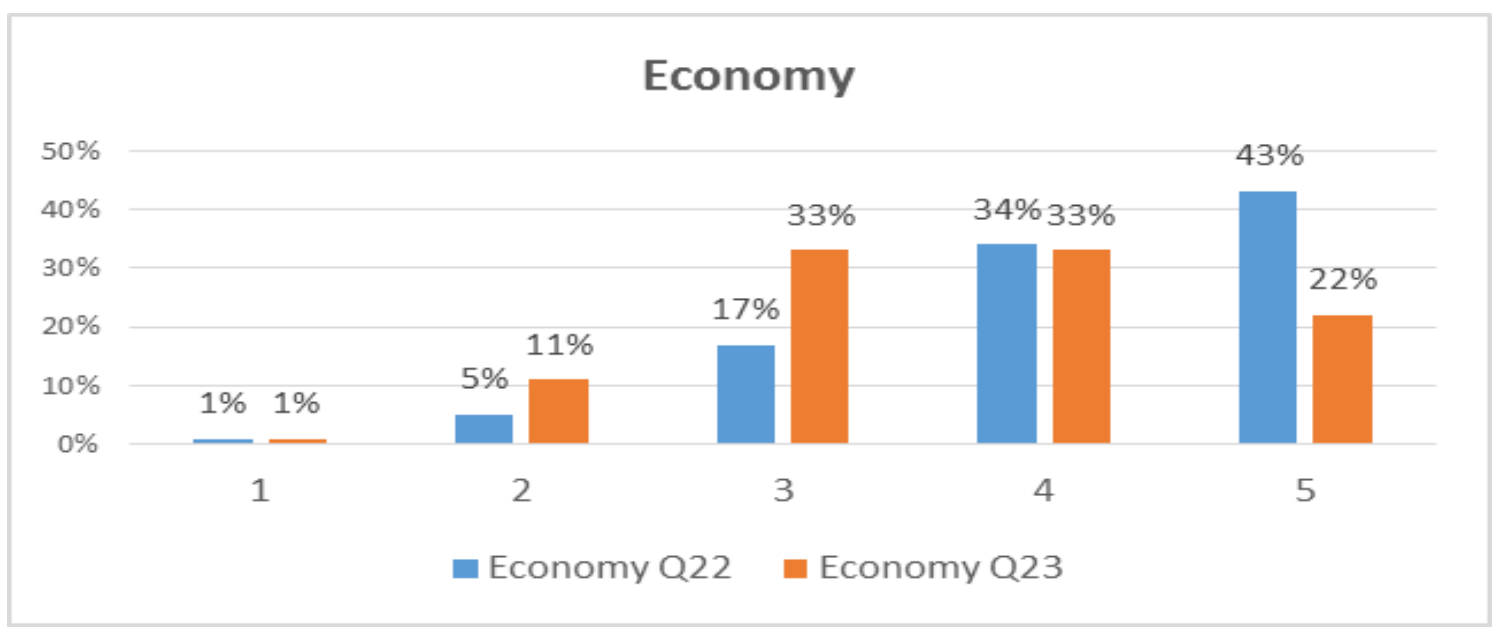

Picture 8. Content Gratifications-Economy (Question 22,23)

Source: Researcher

Q22 : I read GENTA Magazine because I don't have to pay to read it.

Q23 : I read GENTA Magazine because it helps me to find the products and service that I need.

\section{Process Gratification -Exploration(24)}

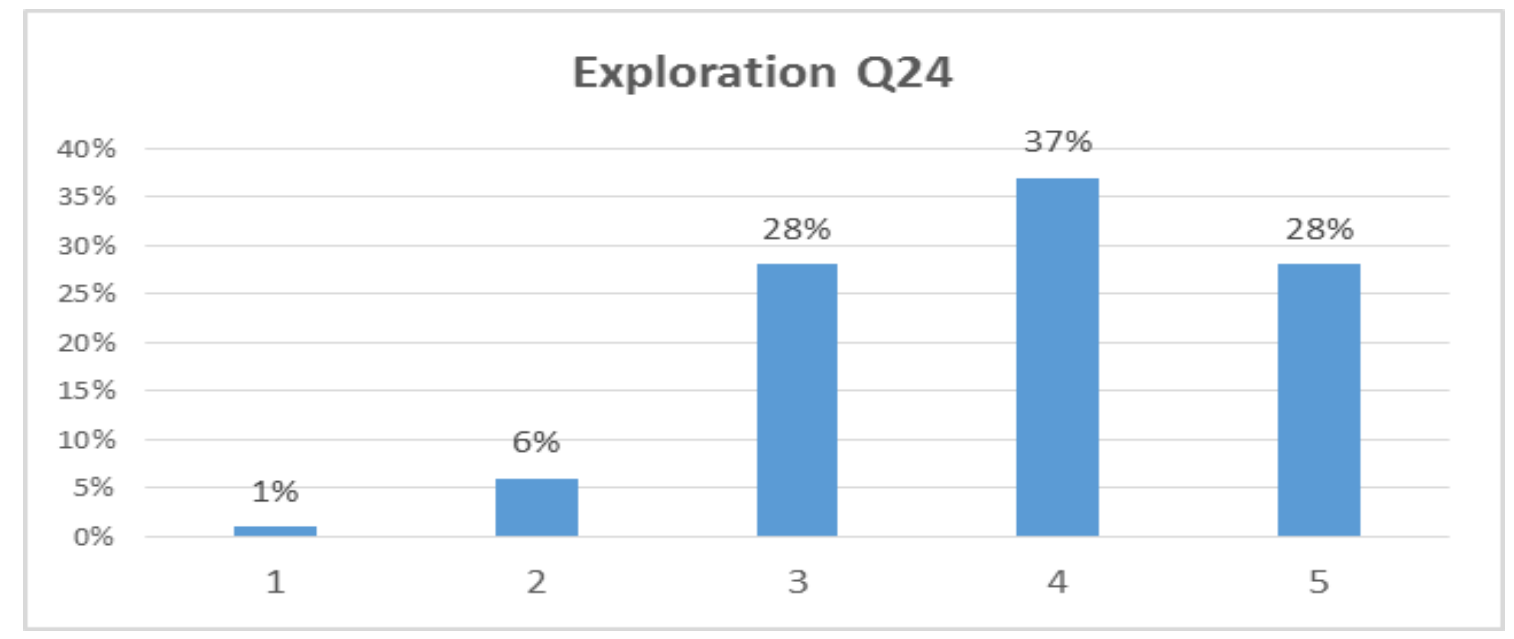

Picture 9. Process Gratifications-Exploration (Question 24)

Source: Researcher

Q24 : I read GENTA Magazine I'm eager to check the newest of GENTA Magazine. 


\section{Gratification Scale}

To determine the mean of the response of Social Gratifications, Content Gratifications, and Process Gratifications, an average calculation of all question is carried out with the following formula (Simamora, 2004)

$$
\mathrm{I}=\frac{m-n}{b}
$$

I : interval

m : highest score

n : lowest score

b : total class

Based on Likert scale, the highest score is 5 and the lowest score is 1 , while the class is 3

(Social Gratifications, Content Gratifications, and Process Gratifications).

$$
I=\frac{5-1}{3} \quad I=1,33
$$

\section{4}

The motive categorized High/Medium/Low if:

$\begin{array}{ll}\text { High }^{3} & : 3,68-5 \\ \text { Medium } & : 2,34-3,67 \\ \text { Low } & : 1-2,33\end{array}$

\section{Gratification Factor}

\begin{tabular}{|c|c|c|c|c|c|c|c|c|}
\hline \multicolumn{9}{|c|}{ SOCIAL GRATIFICATIONS $(\mathrm{X})$} \\
\hline & SD & $\mathrm{D}$ & $\mathrm{N}$ & A & SA & TOTAL & SI MEAN & MEAN \\
\hline \multicolumn{9}{|l|}{$\mathrm{X} 1$} \\
\hline a & 1 & 11 & 29 & 40 & 19 & 3,65 & \multirow{2}{*}{3,675} & \multirow{5}{*}{3,5225} \\
\hline b & $\underline{1}$ & $\underline{11}$ & $\underline{25}$ & 43 & $\underline{20}$ & $\underline{3}$, & & \\
\hline $\mathrm{X} 2$ & & & & & & & & \\
\hline $\mathrm{a}$ & 2 & 19 & 33 & 30 & 16 & 3,39 & \multirow[t]{2}{*}{3,37} & \\
\hline b & 2 & 17 & 37 & 32 & 12 & 3,35 & & \\
\hline
\end{tabular}

Table. 4 Social Gratifications

Source: Researche 
Based on the table above, the mean indicator of Social Gratifications is 3,5225, this is the lowest score of the gratification motives in medium range of the scale. The Status motive has the highest score $(3,7)$ for the statement 'I read GENTA Magazine because "Surabaya Corner" rubric make me up to date with everything in Surabaya'. This content is interesting because in this rubric GENTA Magazine writes about places in Surabaya, that usually rarely known. And they like to know about places in Surabaya as an Instagram-able photo spot. Meanwhile the lowest score $(3,35)$ is Interpersonal Utility motive for the statement 'I read GENTA Magazin because it gives me space to express my minds'. It means the readers do not find GENTA Magazine as a medium to express their minds This happen because not all the student of Petra Christian University could be a contributor in GENTA Magazine.

Table. 5 Content Gratification

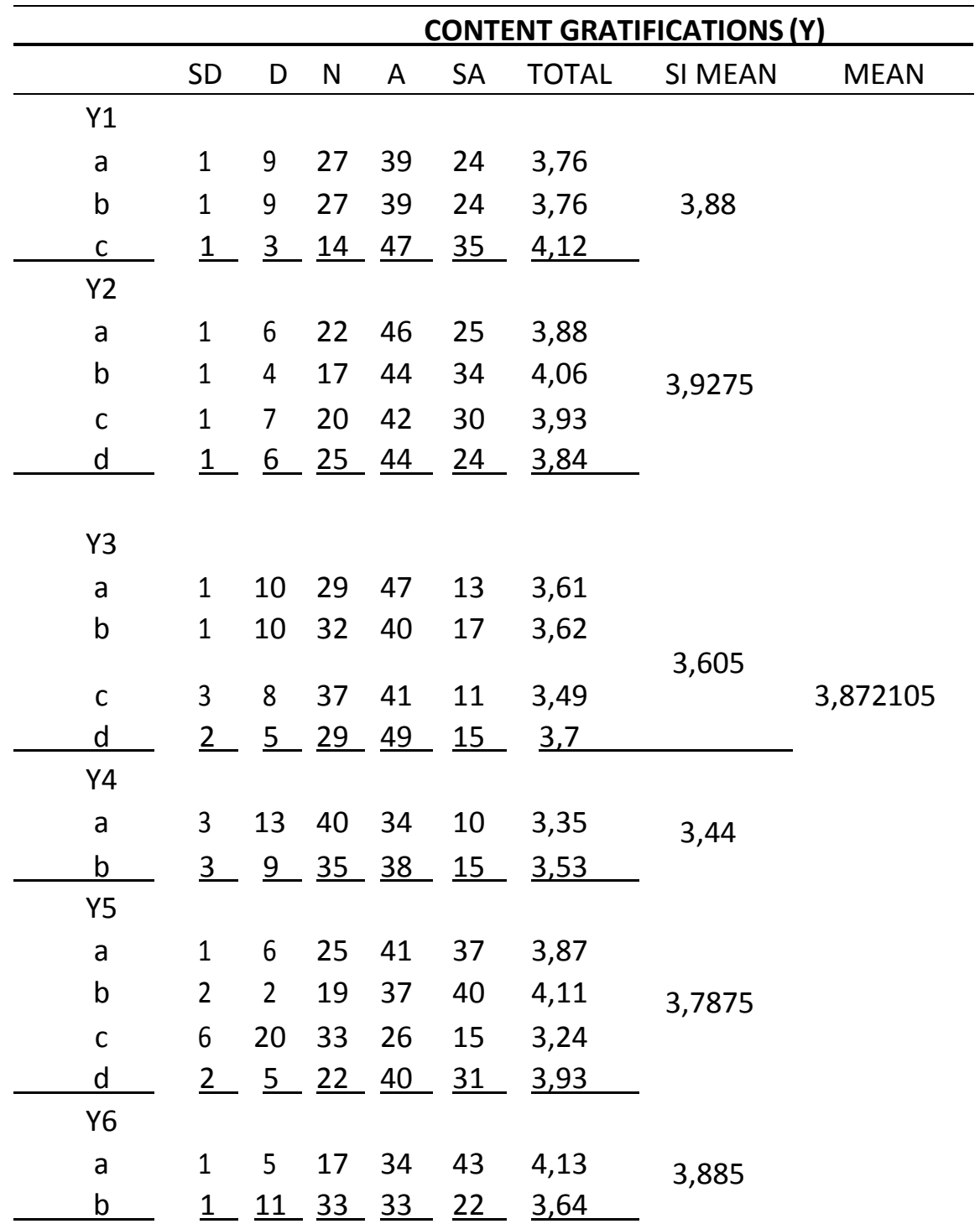

Source: Researcher 
*Y1 = Information Seeking; Y2 = Surveillance; Y3 = Self-Development; Y4 =

Career Opportunitis; Y5 = Diversion; Y6 = Economy

The mean indicator of Content Gratifications is 3,872105 , this is the highest score of the gratification motives in high range of the scale. Most of Petra Christian University students read GENTA Magazine because of Surveillance motive $(3,9275)$. And the sub-indicator motive with the highest is the statement 'I read GENTA Magazine because "Tentang Petra" rubric gives information about new facilities or events in Petra Christian University'. It happened because Petra Christian

University consists of 3 main building, which each of bureau also spread across that 3 building that made the students barely know about it. The lowest score is Career Opportunities motive with 3,44 and the lowest statement 'I read GENTA Magazine because it helps me decide the job that match for me'. Because there is actually no rubric about career that specifically discuss about that.

As the highest mean indicator is the Content Gratification with score 3,872105. Petra Christian University students' motives to read GENTA Magazine is for acquiring trusted and reliable information quickly and cheaply especially about Petra Christian University. They also read GENTA Magazine to develop themselves by interesting ideas to be more creative and prepare themselves for job opportunities by the content provided. GENTA Magazine also come with good quality of illustrations and photographic content that makes them more interested to find entertainment to pass their time. And mostly, they read GENTA Magazine because it is affordable, the student press distributes GENTA Magazine for free.

\begin{tabular}{|llllllll|}
\hline \multicolumn{10}{|c|}{ PROCESS GRATIFICATIONS (Z) } \\
\hline Z1 & SD & D & N & A & SA & TOTAL & \\
a & 1 & 6 & 28 & 37 & 28 & 3,85 & $\mathbf{3 , 8 5}$ \\
\hline
\end{tabular}

Table. 6 Process Gratification

Source: Researcher

$* \mathrm{Z} 1=$ Exploration

Meanwhile the Process Gratification got 3,85 for Exploration motives. Petra Christian University students are eager to check the newest edition of GENTA

Magazine.

\section{CONCLUSION}

The highest gratification motives of GENTA Magazine's audience is content gratifications with 3,87. Most of Petra Christian University students read GENTA
Magazine because of Surveillance motive $(3,9275)$. In surveillance motives, media use aimed to obtaining information about the world and this research it means by the information about university and Surabaya. It makes them up-to-date with events and trends 
and also interested with the stories in the media. In the highest statement 'I read GENTA Magazine because "Tentang Petra" rubric gives information about new facilities or events in Petra Christian University'. It happened because Petra Christian University consists of 3 main building, which each of bureau also spread across that 3 building that made the students barely know about it.

\section{REFERENCES}

Abrahamson, David, and Marcia Prior-Miller. The Routledge Handbook of Magazine Research: the Future of the Magazine Form. Routledge, Taylor Et Francis Group, 2015.

Achmad, Zainal Abidin. "Perbandingan Sistem Pers." Lutfansah Mediatama, 2014.

Bryant, Jennings. Media Effects: Advances in Theory and Research. Lawrence Erlabaum Associates, 2002.

Faiz, Pan Mohammad. "Hukum Dan Pers Mahasiswa." Pan Mohamad Faiz, S.H., M.C.L., Ph.D., 8 Oct. 2006, panmohamadfaiz.com/2006/10/08/huku m-dan-pers-mahasiswa/.

Galloway, John J. "Audience Uses and Gratifications: An Expectancy Model." Communication Research, vol. 8, no. 4, 1 Oct. 1981, pp. 435-449., doi:10.1177/009365028100800403.

Gani, Prita Kemal. "Komunikasi Melalui Media Internal." Prita Kemal Gani, 13 May 2013 , www.lspr.edu/pritakemalgani/komunika si-melalui-media-internal/.

Haryanto, Alexander. "Najwa Paparkan Data Soal Rendahnya Minat Baca Indonesia." Tirto.id, Tirto.id, 14 Aug. 2017, tirto.id/najwa-paparkan-data-soalrendahnya-minat-baca indonesia-cupM.
Jere, M. G., and S. V. Davis. "An application of uses and gratifications theory to compare consumer motivations for magazine and Internet usage among South African women's magazine readers." Southern African Business Review 15.1 (2011): 127.

Katz, Elihu, et al. "Uses and Gratifications Research." Public Opinion Quarterly, vol. 37, no. 4, 973, p. 509., doi:10.1086/268109.

Lichtenstein, Allen, and Lawrence B. Rosenfeld. "Uses And Misuses Of Gratifications

Miller, Katherine. Communication theories: Perspectives, processes, and contexts. McGraw-Hill Humanities/Social Sciences/Languages, 2004.

McQuail, Denis, et al. Communication Theory \& Research: an ECJ Anthology. SAGE Publications, 2007.

McQuail, Denis. McQuail's Reader in Mass Communication Theory. Sage Publications, 1994.

Rizky, Satya. "PERS MAHASISWA: Yang Patah Akan Kembali Tumbuh.." Kognisia, 27 Nov. 2017, kognisia.co/2017/11/27/persmahasiswa-yang-patah-akan-kembalitumbuh/.

Research." Communication Research, vol. 10, no. 1, 1 Jan. 1983, pp. 97-109., doi:10.1177/009365083010001005.

Roinicki, Tom E. "Pengantar Dasar Jurnalisme (Scholastik Journalism)." (2008).

Rosengren, K. E. (1974). Uses and Gratifications: A paradigm outlined. In J. G. Blumler \& E. Katz (Eds), The Uses of Mass Communications: Current Perspectives on Gratifications Research (pp. 269-286). Beverly Hills, CA: Sage. 
Ruggiero, Thomas E. "Uses and Gratifications Theory in the 21st Century." Mass Communication and Society, vol. 3, no. 1, 2000, pp. 3-37., doi:10.1207/s15327825mcs0301_02.

Schramm, et.al. "Empat Teori Pers." Jakarta: PT Intermasa, Terjemahan (1986).

Simamora, Bilson. "Riset pemasaran: Falsafah, teori, dan aplikasi." Jakarta: PT Gramedia Pustaka Utama (2004).
Undang-Undang Republik Indonesia Nomor 40 Tahun 1999 Pers. 23 September 1999. Lembaran Negara Republik Indonesia Tahun 1999 Nomor 166. Jakarta.

Wilson, Logan, and Hadley Cantril. "The Psychology of Social Movements." The American Journal of Psychology, vol. 55 , no. 3, 1942 , p. 462., doi:10.2307/1417494. 